https://doi.org/10.15407/ujpe63.8.754

A. HASHIM, ${ }^{1}$ A. HADI ${ }^{2}$

${ }^{1}$ University of Babylon, College of Education for Pure Sciences, Department of Physics (Iraq; e-mail: ahmed_taay@yahoo.com)

${ }^{2}$ University of Babylon, College of Materials, Department of Ceramics and Building Materials (Iraq)

\title{
NOVEL PRESSURE SENSORS \\ MADE FROM NANOCOMPOSITES (BIODEGRADABLE POLYMERS-METAL OXIDE NANOPARTICLES): FABRICATION AND CHARACTERIZATION
}

\begin{abstract}
This paper aims to the preparation of novel pressure-sensitive nanocomposites with low cost, light weight, and good sensitivity. The nanocomposites of polyvinyl alcohol, polyacrylic acid, and lead oxide nanoparticles have been investigated. The dielectric properties and dc electrical conductivity of ( $\left.\mathrm{PVA}-\mathrm{PAA}-\mathrm{PbO}_{2}\right)$ nanocomposites have been studied. The dielectric properties of nanocomposites were measured in the frequency range $(100 \mathrm{~Hz}-5 \mathrm{MHz})$. The experimental results showed that the dielectric constant and dielectric loss of ( $\left.\mathrm{PVA}-\mathrm{PAA}-\mathrm{PbO}_{2}\right)$ nanocomposites decrease, as the frequency increases, and they increase with the concentrations of $\mathrm{PbO}_{2}$ nanoparticles. The ac electrical conductivity of $\left(\mathrm{PVA}-\mathrm{PAA}-\mathrm{PbO}_{2}\right)$ nanocomposites increases with the frequency and the concentrations of $\mathrm{PbO}_{2}$ nanoparticles. The dc electrical conductivity of (PVA-PAA-PbO 2$)$ nanocomposites also increases with the concentrations of $\mathrm{PbO}_{2}$ nanoparticles. The application of pressure-sensitive nanocomposites has been examined in the pressure interval (60-200) bar. The results showed that the electrical resistance of ( $\left.\mathrm{PVA}-\mathrm{PAA}-\mathrm{PbO} \mathrm{O}_{2}\right)$ pressure-sensitive nanocomposites decreases, as the compressive stress increases. The ( $P V A-$ $\mathrm{PAA}-\mathrm{PbO}_{2}$ ) nanocomposites have high sensitivity to pressure.
\end{abstract}

Ke ywords: sensitivity, piezonanocomposites, resistance, pressure, dielectric properties.

\section{Introduction}

Flexible pressure-sensitive sensors reveal the advantage over traditional pressure-sensitive sensors and some unique characteristics. They can be used to perceive external forces supplied onto the surface, even bended or folded, and to detect the pressure of any two flexible or soft/rigid contact surfaces. Recently, many flexible pressure-sensitive sensors have been reported. The sensing mechanisms include the capacitive sensing, field-effect transistors, piezoelectricsensing, and piezoresistive-sensing. Pressure-sensitive materials based on piezoresistive-sensing mechanisms are widely used owing to their attractive advantages,

(C) A. HASHIM, A. HADI, 2018

754 including feasible preparation, low cost, and easy signal collection. Therefore, they have potentiality to be used to develop flexible pressure-sensitive sensors [1]. The use of polymer piezoelectric materials is certainly desirable, because they have special advantages over ceramics. They are flexible, mechanically more stable, and can be obtained in the form of large-area thin films. Other advantages of polymers are that they can be easily manufactured at much lower temperatures and can be formed more easily with different shapes. Polymers as sensors and actuators offer the advantage of processing flexibility, because they are tough, lightweight, readily manufactured into large areas, and can be cut and formed into complex shapes. Other notable features of poly-

ISSN 2071-0194. Ukr. J. Phys. 2018. Vol. 63, No. 8 
mers are high strength, high impact resistance, low dielectric constant, low elastic stiffness, and low density, which result in a high voltage sensitivity (excellent sensor characteristic), and low acoustic and mechanical impedance (crucial for medical and underwater applications). The purpose of the mixing of piezoelectric ceramics with polymers is to combine the advantages of both materials, which include the mechanical flexibility of polymers and the higher coupling factor [2]. There is the increasing research interest in polymeric nanocomposites owing to improvements in electrical, thermal, optical, and mechanical properties and to their great potential for highly functional materials [3]. Two types of inorganic particles can be used as fillers in polymers for preparing composite materials, i.e., porous and nonporous. Inorganic nonporous nanoparticles have also been introduced into the polymer matrix to prepare a polymer-inorganic nanocomposite [4]. The nanocomposites applications are promising in the industrial and medical approaches of sensors, medical devices, drug delivery, coatings, adhesives, optical integrated circuits, automobiles, microelectronic packaging, injection molded products, packaging materials, aerospace etc. [6-9]. Polymers have several advantages such as the low cost, easy processing, high strength, flexibility, and good mechanical properties [10-12]. Nanocomposites on the basis of semiconductor nanoparticles and a polymer matrix are prospective materials for the application in optoelectronics and sensor electronics, for the creation of luminescent materials, etc. [13].

\section{Materials and Methods}

Nanocomposites films of polyvinyl alcohol (PVA), polyacrylic acid (PAA)-lead oxide $\left(\mathrm{PbO}_{2}\right)$ nanoparticles have been prepared with different concentrations of the polymer blend and metal oxide nanoparticles. The nanocomposites were fabricated withthe following weight percentages of polymers: PVA (83 wt.\%), PAA (17 wt.\%). $\mathrm{PbO}_{2}$ nanoparticles were added to the (PVA-PAA) blend with different concentrations $(0,2.5,5$, and 7.5$)$ wt.\%. The films of nanocomposites were prepared, by using the casting technique The dc electrical properties of (PVA-PAA$\mathrm{PbO}_{2}$ ) nanocomposites are measured by measuring the dc electrical resistance at room temperature, by using the Keithley electrometer type 2400 source meter. The dielectric properties of (PVA-PAA- $\left.\mathrm{PbO}_{2}\right)$

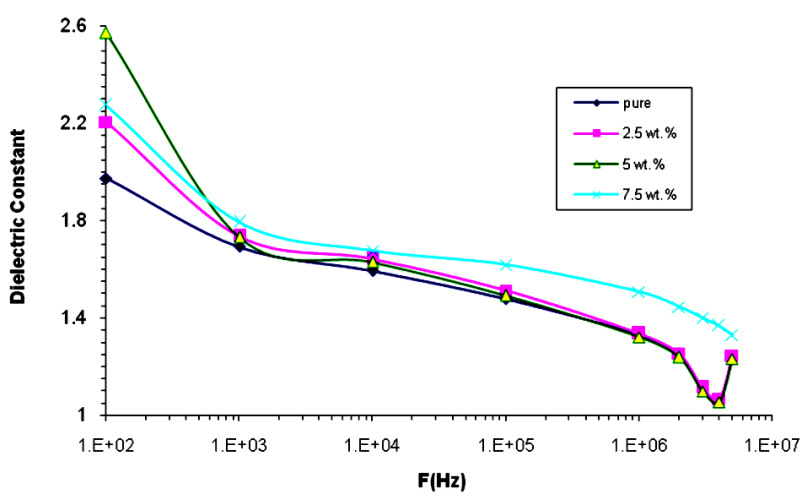

Fig. 1. Variation of the dielectric constant for (PVA-PAA$\mathrm{PbO}_{2}$ ) nanocomposites with the frequency

nanocomposites were examined in the frequency range (from $100 \mathrm{~Hz}$ to $5 \times 10^{6} \mathrm{~Hz}$ ), by using an LCR meter HIOKI 3532-50 LCR HI TESTER. The pressure sensor application of (PVA-PAA- $\left.\mathrm{PbO}_{2}\right)$ nanocomposites was investigated by measuring the resistance between two electrodes on the top and bottom of the samples of (PVA-PAA- $\left.\mathrm{PbO}_{2}\right)$ nanocomposites for different pressures (80-200) bar. The dc electrical specific conductivity $(\sigma)$ of $\left(\mathrm{PVA}-\mathrm{PAA}-\mathrm{PbO}_{2}\right)$ nanocomposites in a sample is determined by the formula [14]:

$\sigma=\frac{d}{R A}$,

where $d$ is the distance between two plates, $A$ is the area of the sample, and $R$ is the electrical resistance.

\section{Results and Discussion}

Figure 1: shows a variation of the dielectric constant for $\left(\mathrm{PVA}-\mathrm{PAA}-\mathrm{PbO}_{2}\right)$ nanocomposites with the frequency at room temperature. As shown in the figure, it is clear that the values of the dielectric constant are very high at low frequencies. Such high values of the dielectric constant at low frequencies has been explained by the presence of space charge effects, which is contributed by the accumulation of charge carriers near the electrodes. At higher frequencies, the dielectric constant has been found to be relatively constant with a change in the frequency. This is because the periodical reversal of the field takes place so rapidly that the charge carriers will hardly be able to orient themselves in the field direction, which results in a decrease in the dielectric constant [15]. In addition, the dielectric constant decreases, as the frequency increases, for all concentrations may be due 


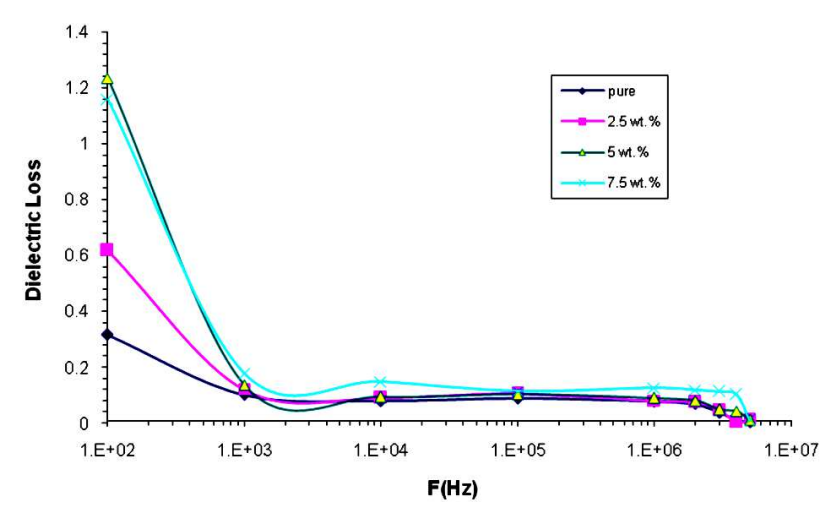

Fig. 2. Variation of the dielectric losses for (PVA-PAA$\mathrm{PbO}_{2}$ ) nanocomposites with the frequency

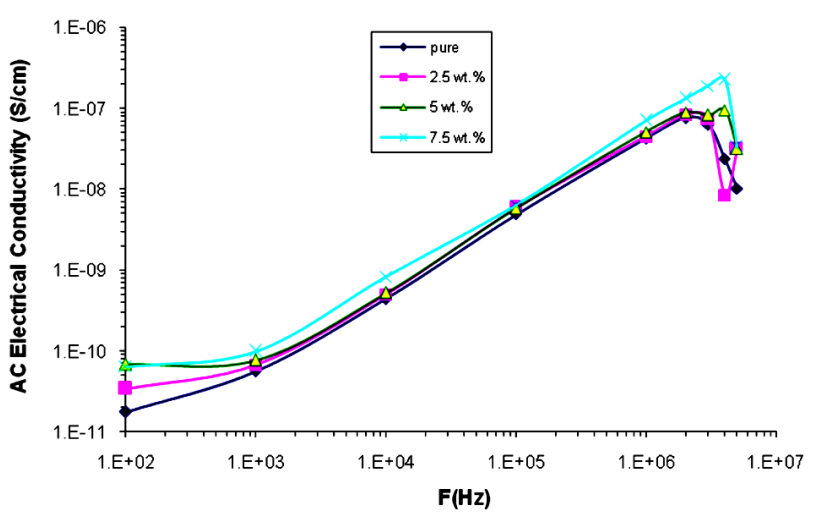

Fig. 3. Variation of the ac electrical conductivity for (PVA$\left.\mathrm{PAA}-\mathrm{PbO}_{2}\right)$ nanocomposites with the frequency

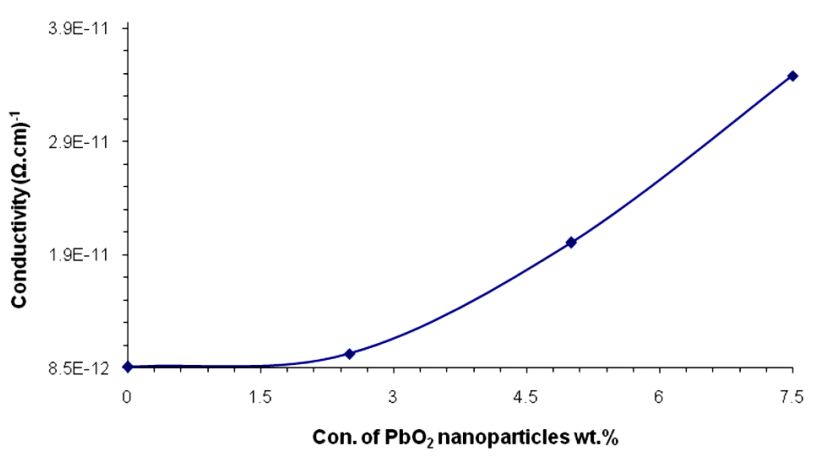

Fig. 4. Variation of the dc electrical conductivity for (PVA$\mathrm{PAA}-\mathrm{PbO}_{2}$ ) nanocomposites with the concentration of $\mathrm{PbO}_{2}$ nanoparticles

to the relaxation process [16]. A variation of the dielectric losses for (PVA-PAA- $\mathrm{PbO}_{2}$ ) nanocomposites with the frequency is shown in Fig. 2. From the figure, it is observed that the dielectric losses decrease, as the frequency increases. This situation has been at-

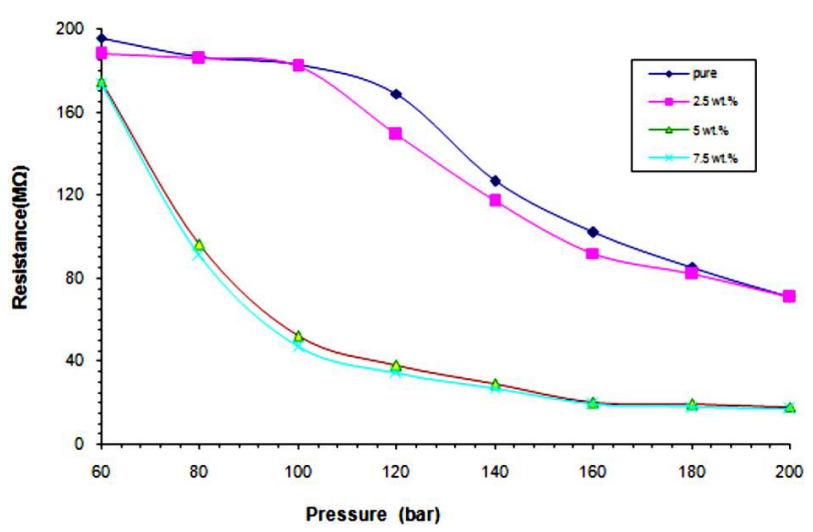

Fig. 5. Variation of the electrical resistance for (PVA-PAA$\mathrm{PbO}_{2}$ ) nanocomposites with the pressure
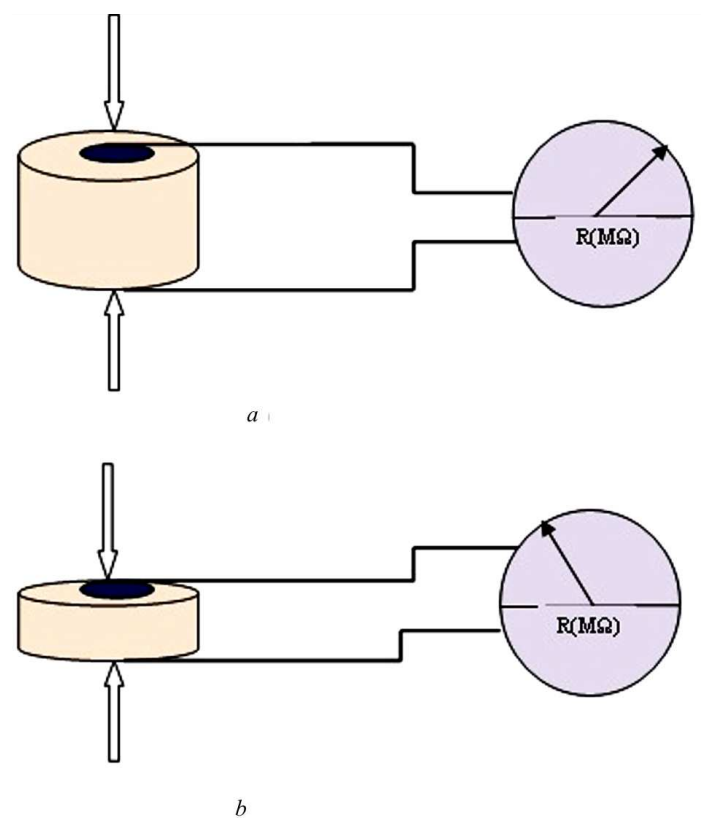

Fig. 6. Schematic view of the pressure-sensitive nanocomposites: before the applied pressure $(a)$ and after the applied pressure $(b)$

tributed to the fact that, in the low-frequency range, there are all types of polarization. Consequently, the losses due to those types of polarization increase. In the high-frequency range, the types of polarization are decreased, and this is accompanied by a decrease in losses [17].

Figures 2 and 3 show the dielectric constant and dielectric losses of a (PVA-PAA) blend, which increase with the concentration of $\mathrm{PbO}_{2}$ nanoparticles. This behavior is related to an increase in the polarizations

ISSN 2071-0194. Ukr. J. Phys. 2018. Vol. 63, No. 8 
of free electrons and space charges, while increasing the concentration of $\mathrm{PbO}_{2}$ nanoparticles [17].

Figure 3 shows a variation of the ac electrical conductivity for (PVA-PAA- $\mathrm{PbO}_{2}$ ) nanocomposites with the frequency at room temperature. The increase of the ac electrical conductivity with frequency is common for polymeric and semiconductor samples. As the filler concentration is increased, the inorganic filler molecules start bridging the gap separating the two localized states and lowering the potential barrier between them, thereby facilitating the charge transfer between two localized states. The frequencydependent conductivity is caused by the hopping of charge carriers in the localized state. The hopping refers to the sudden displacement of charge carriers from one position to another neighboring site and, in general, includes both jumps over a potential barrier and the quantum mechanical tunneling [18]. As shown in the figure, the ac electrical conductivity of the (PVA-PAA) blend increases with the concentration of $\mathrm{PbO}_{2}$ nanoparticles. This result can be attributed to an increase in the conductivity as a result of the increasing charge carrier density in the polymer matrix $[19,20]$.

Figure 4 shows a variation of the dc electrical specific conductivity for ( $\mathrm{PVA}-\mathrm{PAA}-\mathrm{PbO}_{2}$ ) nanocomposites with the concentration of $\mathrm{PbO}_{2}$ nanoparticles at room temperature. From the figure, the dc electrical specific conductivity of the (PVA-PAA) blend increases with theconcentration of $\mathrm{PbO}_{2}$ nanoparticles, which may be attributed to an increase in the number of free charge carriers [21-23].

Figure 5 shows a variation of the electrical resistance for (PVA-PAA-PbO ${ }_{2}$ ) nanocomposites with the pressure at different concentrations of $\mathrm{PbO}_{2}$ nanoparticles. As shown in the figure, the electrical resistance of nanocomposites decreases, as the pressure increases. The explanation of the electrical resistance behavior for nanocomposites with the pressure is as follows: the $\mathrm{PbO}_{2}$ nanoparticles are aggregated as clusters in the (PVA-PAA) blend [24], hence, the resistance is high, as shown in Fig. 6, a. Applying the pressure causes a decrease in the distance between filler particles inside the matrix and an increase in the number of conductive paths, which leads to a decrease in the resistance of composites [25]. Hence, the resistance is low, as shown in Fig. $6, b$. The (PVA-PAA- $\mathrm{PbO}_{2}$ ) nanocomposites combine the advantages of individual materials; for example, the flexibility and processability of a (PVA-PAA) blend and the selectivity, mechanical properties, electrical properties, and thermal stability of $\mathrm{PbO}_{2}$ nanoparticles. The (PVA-PAA- $\left.\mathrm{PbO}_{2}\right)$ pressure-sensitive nanocomposites have high sensitivity for the pressure, low cost, easy processing, and lightweight. This is similar to the results of researchers in [26-28].

\section{Conclusions}

1. The dielectric constant, dielectric losses, and ac electrical conductivity of the (PVA-PAA) blend for pressure-sensitive nanocomposites increase with the concentration of $\mathrm{PbO}_{2}$ nanoparticles.

2. The dielectric constant and dielectric losses of (PVA-PAA- $\left.\mathrm{PbO}_{2}\right)$ pressure-sensitive nanocomposites decrease with an increase in the frequency, while the ac electrical conductivity increases with the frequency.

3. The dc electrical specific conductivity of the (PVA-PAA) blend for pressure-sensitive nanocomposites increases with the concentration of $\mathrm{PbO}_{2}$ nanoparticles.

4. The electrical resistance of (PVA-PAA- $\left.-\mathrm{PbO}_{2}\right)$ pressure-sensitive nanocomposites decreases with an increase in the pressure in the interval 80-200 bar.

5. The (PVA-PAA- $\left.\mathrm{PbO}_{2}\right)$ pressure-sensitive nanocomposites have high sensitivity for the pressure.

1. H. Mei, C. Zhang, R. Wang, J. Feng, T. Zhang. Impedance characteristics of surface pressure-sensitive carbon black/silicone rubber composites. Sensors and Actuators A 233, 118 (2015).

2. A.M. Martínez. Polyimides for Piezoelectric Materials, Magnetoelectric Nanocomposites and Battery Separators: Synthesis and Characterization, PhD Thesis (Universidad del País Vasco, 2016).

3. H.N. Chandrakala, Shivakumaraiah, H. Somashekarappa, R. Somashekar, S. Chinmayee, Siddaramaiah. Poly(vinyl alcohol)/zincoxide-ceriumoxide nanocomposites: Electrical, optical, structural and morphological characteristics. Indian J. Adv. in Chem. Sci. 2, 103 (2014).

4. M.K. Mohanapriya, Kalim Deshmukh, M. Basheer Ahamed, K. Chidambaram, S.K. Khadheer Pasha. Zeolite 4A filled poly (3,4-ethylenedioxythiophene): (polystyrenesulfonate) (PEDOT: PSS) and polyvinyl alcohol (PVA) blend nanocomposites as high- $k$ dielectric materials for embedded capacitor applications. Adv. Mater. Lett. 7 (12), 996 (2016).

5. A. Hashim, A. Hadi. Novel lead oxide polymer nanocomposites for nuclear radiation shielding applications. Ukr. J. Phys. 62 (11), (2017).

6. I.R. Agool, K.J. Kadhim, A. Hashim. Fabrication of new nanocomposites: (PVA-PEG-PVP) blend-zirconium oxide 
nanoparticles) for humidity sensors. Int. J. Plastics Technol. 21 (2), (2017).

7. A. Hashim, Q. Hadi. Structural, electrical and optical properties of (biopolymer blend/ titanium carbide) nanocomposites for low cost humidity sensors. J. Mater. Sci.: Materials in Electronics 29, 11598 (2018).

8. A. Hashim, Q. Hadi. Synthesis of novel (polymer blend-ceramics) nanocomposites: structural, optical and electrical properties for humidity sensors. J. Inorganic and Organometallic Polymers and Materials 28 (4), 1394 (2018).

9. Z. Al-Ramadhan, A. Hashim, A.J. Kadham Algidsawi. The

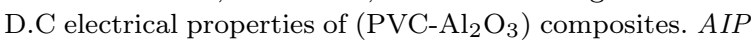
Conf. Proc. 1400 (1), 180 (2011).

10. K.J. Kadhim, I.R. Agool, A. Hashim. Effect of zirconium oxide nanoparticles on dielectric properties of (PVA-PEGPVP) blend for medical application. J. Adv. Phys. 6 (2), 187 (2017).

11. K.J. Kadhim, I.R. Agool, A. Hashim. Synthesis of (PVAPEG-PVP-TiO 2 ) nanocomposites for antibacterial application, materials focus. 5 (5), 436 (2016).

12. F.L. Rashid, A. Hadi, N.H. Al-Garah, A. Hashim. Novel phase change materials, $\mathrm{MgO}$ nanoparticles, and water based nanofluids for thermal energy storage and biomedical applications. Int. J. Pharmaceutical and Phytopharm. Res. 8 (1), (2018).

13. I.R. Agool, K.J. Kadhim, A. Hashim. Preparation of (polyvinyl alcohol-polyethylene glycol-polyvinyl pyrrolidinone-titanium oxide nanoparticles) nanocomposites: Electrical properties for energy storage and release. Int. J. Plastics Technol. 20 (1), 121 (2016).

14. I.R. Agool, K.J. Kadhim, A. Hashim. Synthesis of (PVAPEG-PVP-Z $\mathrm{rO}_{2}$ ) nanocomposites for energy release and gamma shielding applications. Int. J. Plastics Technol. 21 (2), (2017).

15. M. Obula Reddy, B. Chandra Babu. Structural, optical, electrical, and magnetic properties of PVA: $\mathrm{Gd}^{3+}$ and PVA:Ho ${ }^{3+}$ polymer films. Indian J. Mater. Sci. 2015, Article ID 927364 (2015)

16. C.M. Mathew, K. Kesavan, S. Rajendran. Structural and electrochemical analysis of PMMA based Gel electrolyte membranes. Int. J. Electrochem. 2015, Article ID 494308 (2015).

17. A.F. Mansour, S.F. Mansour, M.A. Abdo. Enhancement of structural and electrical properties of $\mathrm{ZnO} / \mathrm{PVA}$ nanocomposites. IOSR J. Appl. Phys. 7 (2), 97 (2015).

18. R. Divya, M. Meena, C.K. Mahadevan, C.M. Padma. Investigation on $\mathrm{CuO}$ dispersed PVA polymer films. J. Engin. Res. and Applic. 4 (5), 1 (2014).

19. A. Hashim, I.R. Agool, K.J. Kadhim. Novel of (polymer blend- $\left.\mathrm{Fe}_{3} \mathrm{O}_{4}\right)$ magnetic nanocomposites: Preparation and characterization for thermal energy storage and release, gamma ray shielding, antibacterial activity and humidity sensors applications. J. Mater. Sci.: Materials in Electronics 29 (12), 10369 (2018).

20. A. Hashim, A. Hadi. A novel piezoelectric materials prepared from (carboxymethyl cellulose-starch) blend-metal oxide nanocomposites. Sensor Lett. 15 (12), (2017).
21. C. Srikanth, C. Sridhar, B.M. Nagabhushana, R.D. Mathad. Characterization and DC conductivity of novel $\mathrm{CuO}$ doped polyvinyl alcohol (PVA) nano-composite films. J. Engin. Res. and Applic. 4 (10), 38 (2014).

22. A. Hadi, A. Hashim. Development of a new humidity sensor based on (carboxymethyl cellulose-starch) blend with copper oxide nanoparticles. Ukr. J. Phys. 62 (12), (2017).

23. A. Hashim, A. Hadi. Synthesis and characterization of novel piezoelectric and energy storage nanocomposites: Biodegradable materials-magnesium oxide nanoparticles. Ukr. J. Phys. 62 (12), (2017).

24. A. Al-Saygh, D. Ponnamma, M.A. AlMaadeed, P. Vijayan, A. Karim, M.K. Hassan. Flexible pressure sensor based on PVDF nanocomposites containing reduced graphene oxidetitania hybrid nanolayers. Polym. 9, 33 (2017).

25. M. Kalantari, J. Dargahi, J. Kövecses, M. Ghanbari Mardasi, S. Nouri. A new approach for modeling piezoresistive force sensors based on semiconductive polymer composites. IEEE/ASME Transactions on Mechatronics 17 (3), (2012).

26. Alamusi, Ning Hu, Hisao Fukunaga, Satoshi Atobe, Yaolu Liu, Jinhua Li. Piezoresistive strain sensors made from carbon nanotubes based polymer nanocomposites. Sensors 11 (11), 10691 (2011).

27. C.-C. Su, C.-H. Li, N.-K. Chang, F. Gao, S.-H. Chang. Fabrication of high sensitivity carbon microcoil pressure sensors. Sensors 12, 10034 (2012).

28. J.-C. Wang, R.S. Karmakar, Y.-J. Lu, C.-Y. Huang, K.-C. Wei. Characterization of piezoresistive PEDOT:PSS pressure sensors with inter-digitated and cross-point electrode structures. Sensors 15, 818 (2015).

Received 13.07.17

\section{A. Хашим, A. Хaдi}

НОВI СЕНСОРИ ТИСКУ 3 НАНОКОМПОЗИТІВ

(ПОЛІМЕРИ, ЩО МОЖУТЬ БУТИ БІОРОЗКЛАДЕНІ,

ТА НАНОЧАСТИНКИ ОКИСЛУ МЕТАЛУ): ВИГОТОВЛЕННЯ І ХАРАКТЕРИСТИКА

$\mathrm{P}$ е $з$ ю м е

Розроблено та досліджено нові нанокомпозити з низькою вартістю і вагою і хорошою чутливістю до тиску на основі полівінілового спирту, поліакрилової кислоти і наночастинок окису свинцю. Виміряні провідність нанокомпозитів за постійним струмом і діелектричні параметри в частотному діапазоні 100 Гц-5 МГц. Експеримент показує, що діелектрична константа і діелектричні втрати PVA-PAA-PbO 2 нанокомпозитів зменшуються з ростом частоти і ростуть зі збільшенням концентрації наночастинок. Провідність нанокомпозитів за змінним струмом зростає з частотою і концентрацією $\mathrm{PbO}_{2}$ наночастинок. Провідність за постійним струмом також збільшується з концентрацією $\mathrm{PbO}_{2}$ наночастинок. Показано, що в інтервалі тисків 60-200 бар опір нанокомпозитів зменшується зі збільшенням тиску за високої чутливості до нього. 